Article

\title{
Analysis of the Consciousness of University Undergraduates for Sustainable Consumption
}

\author{
Miguel Angel Pena-Cerezo ${ }^{1, *}$, Miren Artaraz-Minon ${ }^{2}$ and Jorge Tejedor-Nunez ${ }^{3(-)}$ \\ 1 Department of Financial Economics II, University of the Basque Country, Calle Comandante Izarduy 23, \\ 01006 Vitoria-Gasteiz, Spain \\ 2 Department of Applied Economics V, University of the Basque Country, Calle Comandante Izarduy 23, \\ 01006 Vitoria-Gasteiz, Spain \\ 3 Department of Financial Economics I, University of the Basque Country, Calle Comandante Izarduy 23, \\ 01006 Vitoria-Gasteiz, Spain \\ * Correspondence: miguelangel.pena@ehu.eus; Tel.: +34-945-01-3334
}

Received: 30 June 2019; Accepted: 20 August 2019; Published: 23 August 2019

check for updates

\begin{abstract}
This research seeks to measure the degree of consciousness for sustainable consumption in a wide sample of university students. The interest of this study is to analyze if students' choice of degree, as well as their progress in university education, influences the development of the dimensions that construct the consciousness for sustainable consumption. The study is completed by means of a questionnaire survey aimed at first and final year students of seven university degrees across four different faculties. A factorial analysis of principal components is performed to analyze the dimensions of sustainability and robust contrasts of mean differences are conducted to observe the differences by degrees and years. The results indicate that the measurement scale of the variable consciousness for sustainable consumption maintains its original structure when applied to a sample of Spanish university students. Although there are significant differences by degree in the development of awareness about sustainable consumption, the authors cannot conclude that the training received at the degree level helps to improve the level of awareness of students in their decisions for responsible behavior in consumption.
\end{abstract}

Keywords: higher education; sustainability; undergraduates; responsible behavior; consciousness for sustainable consumption

\section{Introduction}

Sustainability is an issue that has been analyzed by many researchers, but there has been insufficient research on how to measure sustainable behavior as well as develop and validate scales of sustainability constructs with respect to the measurement model [1]. Some authors have considered and explored different parts of responsible consumption through different scales [2-4]. Balderjahn et al. considered sustainability consumption through a sustainability perspective measuring consumer consciousness levels [5]. Furthermore, although several authors have criticized Balderjahn et al. for not paying attention to the behavioral aspect of the consumer [6] or that they only studied a perspective or concrete topic of responsible consumption [7], there have not been any criticisms as to the validity of the scale used.

Travelling the road to sustainability, sustainable consumption should play a prominent role in the formulation and implementation of sustainable development goals (SDGs) $[8,9]$. Consumer behavior is one of the determinants of the impact by society on the environment. This is why this study analyzes what sustainable consumption is and what motivates consumers to practice it [10-12] as well as develop a measure of sustainable consumption awareness [5]. 
It is important to measure sustainable consumption in the context of university students because they are the consumers of the future, they are more educated and informed than the average person [13], will have income capacity, and will be able to influence other people in their workplaces [14]. Sustainable consumption is also a factor that businesses and marketing strategies have to consider. Following this vein, implications for policy and businesses have been proposed $[15,16]$. Concurrently, the authors consider analyzing the relationship between the development of different dimensions of sustainability and students' choice of degree to be relevant [17-20], as well as the progress of the student in their studies [21-23]. The authors want to determine whether students enrolled in courses related to social issues score more in the social dimension of the scale of consciousness for sustainable consumption (CSC), whether those who study economics and business management score higher in the economic dimension, and finally, whether those who study in areas related to the environment score higher in the environmental dimension of the scale.

The awareness of students regarding sustainability, and their perceptions of higher education for sustainable development, depends on different divisions and educational levels [24]. Most business students are not trained to consider the environment as a key factor in business decision-making $[25,26]$. Furthermore, business schools have not changed their curricula to become more socially responsible because, in market-driven MBA programs, the size of the curriculum (i.e., the number of required courses) is cut to make a program more competitive (i.e., allow students to complete the curriculum faster), with the ethics course often one of the casualties [27]. Therefore, it is recommended that social and environmental aspects form part of the ethical framework of business education [28].

\subsection{The Relevance of Sustainability in Higher Education}

The role of education in promoting sustainability envisaged in Agenda 21 [29] has special importance [30]. Hence, the awareness of sustainability in higher education is an issue that is gaining importance [22,31-34] to promote environmentally relevant behavior at all levels [35]. The benefits of these practices are evident: they raise the profile of sustainable university initiatives; provide solutions for sustainability issues; build trust among students, managers, and academics; and promote enriching learning experiences among students. A sustainable university is one that, "apart from seeking academic excellence, tries to embed human values into the fabric of people's lives; a university that promotes and implements sustainability practices in teaching, research, community outreach, waste and energy management, and land use and planning" [14] (p. 105). This approach by the university" not only encourages the institution to look at its own ecological footprint but it also recognizes that students learn from the entire experience of their university career." [13] (p. 63).

Despite this important role of universities, the inclusion of sustainability education in the university curriculum has been very slow [36], particularly in non-environmental disciplines [37]. Although new courses are being offered in a new way, training is still far from containing material that helps to understand the importance of considering environmental sustainability [38,39]. Seen in many universities_-including Spanish ones where the environmental education offered is relatively underdeveloped [40] - sustainability education is limited to a number of specific courses, is often isolated from research, and rarely relates to sustainable activities developed on campus [13]. Consequently, it is suggested that individuals need to be more sensitized and involved through the implementation of effective projects such as collaboration with the economic and social environment [41,42].

Due to the special responsibility of universities in social development, particularly in the education of future leaders and in the promotion of awareness of sustainability [32], the authors agree with Barth et al. [31] when they state that "formal as well as informal learning settings are relevant for developing competencies for sustainable development.“ (p. 427). There are many factors to engage university students with sustainability: psychological (knowledge about the environment); physical (availability of "green" facilities); personal (time availability); social perception (social norms); price (cost of buying "green"); and political (regulatory and management support) [43]. 
Concerning the obstacles perceived by university students to develop responsible behavior, the main difficulties are the lack of communication/awareness, discomfort, financial worries and lack of participation [44], the need for adequate recycling facilities, and the perception that responsibility does not fall on them because their actions are not decisive $[45,46]$.

\subsection{Analysis of the Dimensions of Sustainability among University Students}

Where the sustainability knowledge of students enrolled in university degrees is concerned, several evaluation instruments have been considered so far, such as the compilation of competences or a rubric with sixteen dimensions [47]. Prior to embarking on their studies, more than half of the students did not consider the sustainability of natural or human resources [23]. Those who did were considered to have a positive view of it [17] but, at the same time, the view was naive and ambiguous as it focused on its environmental meaning [48] and because they held the belief that economic growth was unlimited.

Regarding student attitude, most students showed a favorable attitude and developed respectful practices with the environment $[49,50]$. Cotton and Alcock [22] conclude that attendance at university had a significant positive relationship with environmental responsibility. This positive attitude also can be reinforced by the use of rewards, for example, a recognition letter that favors an attitude in support of environmental or social aspects such as the use of seat belts, use of footpaths for pedestrians, return of newspapers, etc. [51]. There is a significant gap between the (high) level of environmental awareness that students claimed to have and the (low) interest in participating in sustainable initiatives $[21,45,52,53]$, therefore, education is a necessary but not sufficient condition in which to develop sustainable behavior. When students perceive that an activity is difficult, they understand that it is not important to carry out and they transfer their responsibility/inactivity to other agents such as the government, companies, or social groups [45].

Regarding the sustainability dimensions, the threefold approach already has an institutional statement $[54,55]$, which recognizes that regardless of the multiple meanings of the term, the three domains-social, environmental, and economic-are basic. Nonetheless, the concept of sustainability has placed greater emphasis on its environmental aspect than on its economic and social approaches and students tend to understand sustainability only from its environmental perspective [19,48,56-61]. The only behavior classified as normative is that of recycling, while no social or economic behavior has been classified as sustainable [45]. Thus, many authors [17,48,51,62,63] have studied the behavior of students by distinguishing the three dimensions of sustainability and possible ways to promote pro-environmental and pro-social behaviors such as turning off lights, donating blood, using seat belts, using pedestrian crossings, or helping with housework. Vallance, Perkins, and Dixon [64] specifically analyze the social dimension of sustainability and propose that sustainability is related to basic social needs such as the creation of social capital to behavioral changes and the pursuit of environmental objectives as well as the preservation of the socio-cultural characteristics of such changes. Meanwhile, there have been relatively few studies of economic sustainability, as most management tools have been analyzed by environmental and social scientists. Some have referred to it vaguely, and, in any case, it is inappropriate for management in the practice of a business [65].

Considering this context, the aim of this article is to provide more accurate information on the beliefs and importance given by university students to the three-dimensional concept of sustainability, by focusing on the perspective of conscious consumption.

\section{Materials and Methods}

\subsection{Hypotheses}

The measurement of sustainability was made by considering its three dimensions, but insufficient research has been conducted on how to measure sustainable behavior by developing and validating scales of sustainability constructs [1]. 
Balderjahn et al. [5,66] deliberates that responsible consumers consider the economic, environmental, or social consequences of their consumer choices. Regarding the expected value model [67] and Elkington's 'triple bottom line' concept [68], they propose a theoretical model that develops a measurement scale for consciousness for sustainable consumption (CSC) that integrates the three dimensions of sustainability. This model contemplates both the expectation that a particular consumption decision has a concrete consequence and the importance that the consequence has for the consumer. The product of both variables is defined as CSC. Thus, the current authors propose analyzing whether the same three dimensions of the CSC could be observed in the Spanish university population. The first hypothesis investigated can be written as follows:

Hypothesis 1 (H1). The consciousness for sustainable consumption of the Spanish consumers is composed of three dimensions: environmental, social, and economic.

Many studies have shown the existence of differences regarding the importance that students give to sustainability according to the type of study chosen. Kagawa [17] detects differences between students in the social and business sciences and those in health and social assistance in relation to feeling familiar with sustainability. Zwickle et al. [19] likewise shows that there are differences among students by degree: aerospace engineering students give greater importance to economic sustainability, even more so than students of economics-related specialties. Furthermore, Chiong [20] concludes that civil engineering students show greater knowledge and interest in sustainability than other engineering students. Sharma et al. [18] analyzes students in different engineering specialties and attributes the differences detected according to specialty in the different levels of previous knowledge and the different learning styles. Based on this, and in the context of Spanish students, the authors propose the second hypothesis:

Hypothesis 2 (H2). There are significant differences in the levels of perceived importance of sustainability dimensions depending on the type of study chosen.

There is no unanimity regarding the degree of development of the dimensions of sustainability throughout the studies. Many studies conclude that environmental attitudes and behaviors are progressively higher as students advance in their studies [17,19,30,61,63,69-72]. To contrast, other authors, such as Kollmuss and Agyeman [73], conclude that a higher level of education does not translate into an increase of behavior in favor of the environment. Meanwhile, Sammalisto [74] states that, although there were changes in the knowledge, concern, and actions related to sustainability in the course of university studies, it is not possible to demonstrate to what extent they are dependent on the education received. Along this same line, Peattie [75] and Laroche et al. [76] state that consumers of organic products tend to have a lower level of education. Given the absence of a clear position on this issue, the authors raise the third hypothesis:

Hypothesis 3 (H3). The knowledge acquired at the university by the students favors the level of perceived development of the dimensions of sustainability.

\subsection{Methodology}

\subsubsection{Sample}

Convenience sampling, which involves students soliciting participants to assist in data collection, has become an increasingly common and important research design feature [77], is increasingly used in organizational research [78], and has important advantages including student learning, cost reduction, and elaborate research designs [79]. 
Shown in Table 1, the sample was composed of students from the first and final years of seven degrees: Environmental Science (ES), Human Nutrition and Dietetics (HND), Food Science and Technology (FST), Pharmacy (Pharmacy), Business Administration and Management (BAM), Engineering (ENG) and Social Work (SW), across four faculties of the University of the Basque Country.

Table 1. Information about the sample.

\begin{tabular}{|c|c|}
\hline Information & Data \\
\hline Population & $\begin{array}{l}\text { University of the Basque Country (UPV/EHU) students ( }>98 \% \\
\text { Spanish citizens). Average age: } 19.5 \text { years old. }\end{array}$ \\
\hline Period of data collection & Fall 2014. \\
\hline University Centers & $\begin{array}{c}\text { Faculty of Economics and Business, Faculty of Pharmacy, Faculty of } \\
\text { Labor Relations and Social Work and University School of } \\
\text { Engineering in Vitoria-Gasteiz. }\end{array}$ \\
\hline Degrees & $\begin{array}{l}\text { Business Administration and Management (BAM), Environmental } \\
\text { Science (ES), Pharmacy (Pharmacy), Food Science and Technology } \\
\text { (FST), Human Nutrition and Dietetics (HND), (Electric, Electronic, } \\
\text { Chemical and Mechanic) Engineering (ENG), and Social Work (SW). }\end{array}$ \\
\hline Years & $\begin{array}{l}\text { First year and final year of each degree (the last year is the } 4^{\text {th }} \text { year, } \\
\text { except for Pharmacy, where the final year is the } 5^{\text {th }} \text { year. The } \\
\text { questionnaire could not be administered in the last year of the } \\
\text { Environmental Science degree). }\end{array}$ \\
\hline
\end{tabular}

The authors consider that the population analyzed has a high degree of exposure to sustainability. The Directorate of Sustainability at this university has the mission of fostering a culture of sustainability and social commitment in both society and the university community. The University is committed to exercising its daily activities in a sustainable way economically, socially, and environmentally. The University is progressing with sustainable management. Collaborative work, university development cooperation, and student participation in solidarity initiatives have been promoted among the different university groups to work on sustainability, and the University works together with entities in the field of sustainability and development cooperation.

Likewise, participation in networks and complementary training in the field of sustainability has been actively encouraged. Since 2004, the University annually organizes specific courses focused on sustainability in the area of cooperation and development education. Some examples include the course "Development and solidarity cooperation" in the Faculty of Labor Relations and Social Work; the course "Development cooperation in the field of nutrition and health" offered in the Faculty of Pharmacy; the course called the "Current challenges of development and cooperation in the Global Economy " offered in the Faculty of Economics and Business; and the course called "Development, Cooperation and Technology Seminar for human development" offered at the University School of Engineering.

Regarding this case, and as it is interdisciplinary and multidisciplinary research, the authors collaborated with several professors from the previously mentioned Faculties to obtain the data from the students in their respective centers. The total number of answers obtained during November 2014 was 711 (see Table 2). The administration of the questionnaire was conducted during the regular teaching period, in the classes imparted by the collaborating teachers. Students' participation was voluntary (not compulsory). The response rate was maximum (close to $100 \%$ ) due fundamentally to the teacher's exposition of the relevance of the study and its objectives. 
Table 2. Distribution of questionnaires by gender, center, and degree.

\begin{tabular}{|c|c|c|c|c|c|c|c|c|}
\hline \multirow{2}{*}{$\begin{array}{l}\text { Centre } \\
\text { Degree }\end{array}$} & \multirow{2}{*}{$\begin{array}{c}\begin{array}{c}\text { Faculty of } \\
\text { Economics and } \\
\text { Business }\end{array} \\
\text { BAM }\end{array}$} & \multicolumn{4}{|c|}{ Faculty of Pharmacy } & \multirow{2}{*}{$\begin{array}{c}\begin{array}{c}\text { University } \\
\text { School of } \\
\text { Engineering }\end{array} \\
\text { ENG }\end{array}$} & \multirow{2}{*}{$\begin{array}{c}\text { Faculty of Labor } \\
\text { Relations and } \\
\text { Social Work }\end{array}$} & \multirow{2}{*}{$\begin{array}{c}\text { TOTAL } \\
\text { (all) }\end{array}$} \\
\hline & & ES & FST & Pharmacy & HND & & & \\
\hline First year & 74 & 45 & 20 & 121 & 52 & 45 & 78 & 435 \\
\hline Last year & 44 & 0 & 29 & 60 & 30 & 45 & 68 & 276 \\
\hline $\begin{array}{c}\text { Total } \\
\text { (Female\%) }\end{array}$ & $\begin{array}{c}118 \\
(47 \%)\end{array}$ & $\begin{array}{c}45 \\
(49 \%)\end{array}$ & $\begin{array}{c}49 \\
(75 \%)\end{array}$ & $\begin{array}{c}181 \\
(76 \%)\end{array}$ & $\begin{array}{c}82 \\
(77 \%)\end{array}$ & $\begin{array}{c}90 \\
(22 \%)\end{array}$ & $\begin{array}{c}146 \\
(74 \%)\end{array}$ & $\begin{array}{c}711 \\
(60 \%)\end{array}$ \\
\hline
\end{tabular}

Note: BAM refers to Business Administration and Management Degree; ES: Environmental Science Degree; Pharmacy: Pharmacy Degree; FST: Food Science and Technology Degree; HND: Human Nutrition and Dietetics Degree; ENG: Electric, Electronic, Chemical and Mechanic Engineering Degrees; and SW: Social Work Degree.

\subsubsection{Measurements}

An adaptation of the Balderjahn et al. [5] scale was used to measure the awareness of sustainable consumption.

According to Mcgorry [80] and Harkness et al. [81], and to ensure that the translation of the scale was understood the same way as the original [82], the authors used the back-translation process and a pilot testing. Thus, a translator translated the English version of the scale from English to Spanish and the authors have ensured that it was culturally adapted [83] to the sample. Next, the authors conducted a pilot test with a set of lecturers and students with knowledge of sustainability to ensure the correct translation of the survey and the meaning of the items that are part of it. During this stage, one of the survey items (the first item linked to Econ_Collab: "I/you don't want to borrow it from friends") was not well understood by the students who conducted the survey, so it was not included in this analysis [84]. Some students understood that the question referred to borrowing money, and not to borrowing the item, which might have led to a misinterpretation of the question. Finally, the authors asked for the help of two bilingual teachers on campus with knowledge of sustainability to perform the English back-translation and check that there were no differences in meaning between the English versions [85].

This scale considers both the expectation that a particular action has a concrete consequence (Belief) and the importance of that consequence for the individual (Importance). Therefore, according to this scale, the authors considered two types of different questions:

Belief: $\quad$ Even if I can financially afford a product, I only buy a product if I believe that (during the manufacturing) ...

Importance: Even if I can financially afford a product, how important is it for me personally that (during the manufacturing of a product) ...

The product of both variables is precisely the consciousness for sustainable consumption, a combination of the perception of the consequences of consumption and the importance associated with those consequences. The scale used was composed of 18 indicators (see Table 3), which corresponded to the three dimensions: environmental (four indicators), social (five indicators), and economic (nine indicators).

Then, in the fall of 2015, 711 undergraduate students from the University of the Basque Country rated (during their classes) their consciousness of sustainable consumption using the resultant 18 indicators on a five-point Likert scale.

Krosnick et al. [86] state that Likert scaling most often uses 5 points. This 5 points scale is also the most used by the American National Election Study [87]. Moreover, Robinson et al. [88] highlight that, following the 2-points scales (not applicable in this research), the 5-points scales are the most used in psychological constructs. Thus, although there appears to be no standard for the number of points on rating scales, and common practice varies widely [86], the current authors have selected a scale of 1-5 for this survey. 
This study followed the methodological, legal and ethical criteria proper to research with human beings and was approved by the university's Ethics board.

There were five main reasons for the choice of this scale of measurement adapted from Balderjahn et al. [5]:

- It considers the three dimensions of sustainability.

- It is an operative measure because there is not a very high number of items that compose it.

- It has appropriate psychometric qualities.

- Three of the four groups used for the validation of this scale [5] corresponded to the student population, coinciding with the analyzed population.

- The geographical scope analyzed by the authors was not very far from theirs from a socio-economic point of view.

The document that contains the questions posed to the students (questionnaire) is available in Appendix A.

Table 3. Measure of Consciousness for Sustainable Consumption (CSC).

\begin{tabular}{|c|c|c|c|}
\hline Dimensions & (Sub) dimensions & Indicators & Questions \\
\hline \multirow{4}{*}{$\begin{array}{l}\text { Environmental } \\
\text { dimension (ENV) }\end{array}$} & & ENV1 & It is made from recycled materials \\
\hline & & ENV2 & $\begin{array}{c}\text { It can be disposed of in an environmentally } \\
\text { friendly manner }\end{array}$ \\
\hline & & ENV3 & $\begin{array}{l}\text { It is packaged in an environmentally } \\
\text { friendly manner }\end{array}$ \\
\hline & & ENV4 & $\begin{array}{l}\text { It is produced in an environmentally } \\
\text { friendly manner }\end{array}$ \\
\hline \multirow{5}{*}{ Social dimension (SOC) } & & SOC1 & Workers' human rights are adhered to \\
\hline & & SOC2 & No illegal child labor is involved \\
\hline & & SOC3 & Workers are not discriminated against \\
\hline & & SOC4 & Workers are not abused \\
\hline & & SOC5 & Workers are treated fairly or are fairly compensated \\
\hline \multirow{9}{*}{$\begin{array}{l}\text { Economic dimension } \\
\qquad(\mathrm{ECON})\end{array}$} & \multirow{3}{*}{$\begin{array}{l}\text { Voluntary simplicity } \\
\text { (SIMP) }\end{array}$} & ECON1 & I really need this product \\
\hline & & ECON2 & It is a useful product \\
\hline & & ECON3 & I absolutely require this product \\
\hline & \multirow{4}{*}{$\begin{array}{l}\text { Debt-free consumption } \\
\quad(\text { NO DEBT) }\end{array}$} & ECON4 & I don't become over indebted in the long term \\
\hline & & ECON5 & $\begin{array}{c}\text { The expenses don't unduly burden my } \\
\text { financial situation }\end{array}$ \\
\hline & & ECON6 & I don't have to forego future purchases \\
\hline & & ECON7 & $\begin{array}{l}\text { I don't have to take money from my financial } \\
\text { reserve for emergency cases for it }\end{array}$ \\
\hline & \multirow{2}{*}{$\begin{array}{c}\text { Collaborative } \\
\text { consumption (COLLAB) }\end{array}$} & ECON8 & $\begin{array}{l}\text { I really need to own it and don't want to share } \\
\text { with others }\end{array}$ \\
\hline & & ECON9 & I don't want to rent or lease it \\
\hline
\end{tabular}

Source: Adapted from [5].

\subsubsection{Statistical Methods}

Three main techniques were used to contrast the work hypotheses: on one hand, an exploratory factor analysis with Varimax rotation; on the other hand, a confirmatory factor analysis (CFA). Finally, an analysis of mean differences using the Brown-Forsythe indicator was completed with a post-hoc analysis.

\section{Results}

\subsection{Structure of the Consciousness of Sustainable Consumption}

The exploratory factor analysis was performed using SPSS IBM 22.0 to analyze the three-dimensional structure of the measurement scale of the consciousness of sustainable consumption resulting in five factors with an eigenvalue greater than unity, which accounted for $79.2 \%$ of the total 
variance. The observation of factorial loads (see Table 4) showed a clear correspondence with the factors obtained by Balderjahn et al. [5], so the original names also were used in this work. Related to the analysis of the reliability of the scales, the value of Cronbach's alpha for each of the five dimensions analyzed was above the recommended levels $[89,90]$. The authors add that the Cronbach's alpha aggregate (calculated jointly for the 18 indicators) ascended to 0.883 , so they considered that the internal consistency of the resulting scale was satisfactory.

Table 4. Exploratory factor analysis (matrix of rotated components) and scale reliability analysis.

\begin{tabular}{|c|c|c|c|c|c|c|}
\hline \multirow{2}{*}{ Indicators } & \multicolumn{2}{|c|}{ Cronbach's } & \multicolumn{3}{|c|}{ Component } & \multirow[b]{2}{*}{ COLLAB } \\
\hline & Alpha & SOC & NODEBT & ENV & SIMP & \\
\hline ENV1 & \multirow{4}{*}{0.929} & 0.252 & 0.840 & -0.009 & 0.031 & 0.009 \\
\hline ENV2 & & 0.292 & 0.873 & 0.059 & 0.028 & 0.016 \\
\hline ENV3 & & 0.339 & 0.870 & 0.005 & 0.019 & 0.022 \\
\hline ENV4 & & 0.463 & 0.789 & 0.025 & 0.050 & 0.024 \\
\hline SOC1 & \multirow{5}{*}{0.957} & 0.853 & 0.317 & 0.086 & 0.001 & 0.031 \\
\hline SOC2 & & 0.884 & 0.237 & 0.075 & 0.022 & 0.008 \\
\hline SOC3 & & 0.909 & 0.235 & 0.017 & 0.003 & 0.042 \\
\hline SOC4 & & 0.911 & 0.221 & 0.063 & 0.043 & 0.030 \\
\hline SOC5 & & 0.821 & 0.325 & 0.058 & 0.064 & 0.024 \\
\hline SIMP1 & \multirow{3}{*}{0.819} & 0.042 & 0.011 & 0.294 & 0.852 & 0.057 \\
\hline SIMP2 & & 0.086 & 0.040 & 0.376 & 0.797 & 0.054 \\
\hline SIMP3 & & -0.029 & 0.053 & 0.151 & 0.763 & 0.273 \\
\hline NODEBT1 & \multirow{4}{*}{0.859} & 0.046 & 0.126 & 0.795 & 0.222 & 0.071 \\
\hline NODEBT2 & & 0.056 & 0.035 & 0.870 & 0.155 & 0.137 \\
\hline NODEBT3 & & 0.054 & -0.101 & 0.780 & 0.182 & 0.243 \\
\hline NODEBT4 & & 0.078 & 0.009 & 0.744 & 0.241 & 0.159 \\
\hline COLLAB1 & \multirow{2}{*}{0.697} & 0.041 & -0.057 & 0.324 & 0.183 & 0.776 \\
\hline COLLAB2 & & 0.043 & 0.081 & 0.196 & 0.141 & 0.849 \\
\hline $\begin{array}{l}\% \text { Total variance explained by each } \\
\text { component }\end{array}$ & & $35.8 \%$ & $23.5 \%$ & $8.1 \%$ & $6.2 \%$ & $5.6 \%$ \\
\hline$\%$ Accumulate explained variance & & $35.8 \%$ & $59.3 \%$ & $67.4 \%$ & $73.6 \%$ & $79.2 \%$ \\
\hline
\end{tabular}

Note: ENV denotes Environmental Dimension; SOC: Social Dimension; ECON: Economic Dimension, with is built on these three subdimensions: SIMP: Voluntary simplicity, NODEBT: Debt-free consumption and COLLAB: Collaborative consumption.

The factor that had a greater explanatory capacity was the one related to the social dimension (SOC), which explained more than a third (35.8\%) of the total variance. The second dimension in order of importance was economic, with a total explanatory capacity of $35.3 \%$, which decomposed into three sub-dimensions or factors: avoidance of indebtedness (ECON_NODEBT: 23.5\%), preference for simplicity (ECON_SIMP: 6.2\%), and collaborative consumption (ECON_COLLAB: 5.6\%). Third was the environmental dimension (ENV), with an explanatory capacity of $8.1 \%$.

Additionally, a confirmatory factor analysis (CFA) was performed using AMOS IBM 25.0. The results of the CFA indicated a good model fit [91]: $\chi^{2}=242.662$ with $124 \mathrm{df}$; Comparative fit index $(\mathrm{CFI})=0.981$; Root mean square error of approximation (RMSEA) $=0.046$; Goodness of fit (GFI): 0.944, and with significant factorial loads above 0.6 in all cases. Two additional measures of reliability were obtained from this analysis: composite reliability (CR) and average variance extracted (AVE), with values above the recommended ones of 0.7 and 0.5 , respectively [92] $\left(\mathrm{CR}_{\mathrm{ENV}}=0.927, \mathrm{CR}_{\mathrm{ECON} \_S I M P}=\right.$ $0.834, \mathrm{CR}_{\mathrm{ECO} \_\mathrm{COLLAB}}=0.706, \mathrm{CR}_{\mathrm{SOC}}=0.955, \mathrm{CR}_{\mathrm{ECO} \_\mathrm{NODEBT}}=0.871 ; \mathrm{AVE} \mathrm{ENV}_{\mathrm{ENV}}=0.763, \mathrm{AVE}_{\mathrm{ECON} \_\mathrm{SIMP}}$ $\left.=0.629, \mathrm{AVE}_{\mathrm{ECO} \_\mathrm{COLLAB}}=0.548, \mathrm{AVE}_{\mathrm{SOC}}=0.808, \mathrm{AVE} \mathrm{ECO}_{\mathrm{ENODEBT}}=0.671\right)$.

It should be concluded that the dimensions present in [5] also were observed in the current sample of Spanish university students, which supposes an endorsement for the first hypothesis. 


\subsection{Relationship between Consciousness of Sustainable Consumption (CSC) Dimensions and Studies Performed}

Shown in Table 5, the average value of each of the five (sub) dimensions that comprised the consciousness of sustainable consumption (CSC) is shown for each of the seven degrees analyzed. The most developed (sub) dimensions were Voluntary simplicity (ECON_SIMP) and Debt-free consumption (ECON_NODEBT), while the least developed was the ENV dimension. This lower importance given by students/consumers to the environmental dimension contrasts with the greater attention given by the scientific community to this same dimension [19,48,56-61].

Table 5. Mean value and differences of the (sub) dimensions of the Consciousness of Sustainable Consumption (CSC), by degree.

\begin{tabular}{|c|c|c|c|c|c|}
\hline $\begin{array}{l}\text { Mean value of the (sub)dimensions of } \\
\qquad \operatorname{CSC}^{a} \text { : }\end{array}$ & SOC & ENV & $\begin{array}{l}\text { ECON }_{-} \\
\text {SIMP }\end{array}$ & $\begin{array}{l}\text { ECON }_{-} \\
\text {NODEBT }\end{array}$ & $\begin{array}{l}\text { ECON } \\
\text { COLLAB }\end{array}$ \\
\hline BAM & 11.50 & 6.93 & 15.30 & 14.78 & 11.15 \\
\hline ES & 15.86 & 12.80 & 17.46 & 16.01 & 11.71 \\
\hline FST & 14.30 & 11.40 & 14.41 & 13.84 & 10.78 \\
\hline PHARMACY & 12.21 & 8.41 & 15.53 & 16.46 & 10.93 \\
\hline HND & 12.97 & 8.63 & 15.74 & 15.61 & 10.27 \\
\hline ENG & 13.19 & 8.86 & 16.20 & 16.11 & 10.72 \\
\hline SW & 14.01 & 10.38 & 14.34 & 14.38 & 10.23 \\
\hline $\begin{array}{l}\text { (Sub) dimension Value } \\
\text { Weighted Average }\end{array}$ & 13.04 & 9.12 & 15.39 & 15.39 & 10.75 \\
\hline Brown-Forsythe equality of averages ${ }^{c}$ : & $3.94^{* * *}$ & $10.81^{* * *}$ & $2.59^{* *}$ & $2.99^{* * *}$ & 0.61 \\
\hline $\begin{array}{l}\text { T2 Tamhane's post hoc difference test } \\
\qquad(\mathrm{i}-\mathrm{j})^{\mathrm{d}}: \\
\begin{array}{ll}\text { (i) } & \text { (j) }\end{array}\end{array}$ & SOC & ENV & $\begin{array}{l}\text { ECON- } \\
\text { SIMP }\end{array}$ & $\begin{array}{c}\text { ECON- } \\
\text { NODEBT }\end{array}$ & $\begin{array}{l}\text { ECON- } \\
\text { COLLAB }\end{array}$ \\
\hline $\begin{array}{c}\text { ES } \\
\text { FST } \\
\text { PHARMACY } \\
\text { HND } \\
\text { ENG } \\
\text { SW }\end{array}$ & $\begin{array}{c}-4.360^{*} \\
2.794 \\
-0.708 \\
-1.468 \\
-1.684 \\
-2.506^{*}\end{array}$ & $\begin{array}{l}-5.869^{*} \\
-4.463^{*} \\
-1.481 \\
-1.697 \\
-1.928 \\
-3.442^{*}\end{array}$ & $\begin{array}{c}-2.154 \\
0.894 \\
-0.232 \\
-0.436 \\
-0.893 \\
0.960\end{array}$ & $\begin{array}{c}-1.233 \\
0.938 \\
-1.684 \\
-0.830 \\
-1.336 \\
0.398\end{array}$ & $\begin{array}{c}-0.556 \\
0.375 \\
0.218 \\
0.880 \\
0.434 \\
0.925\end{array}$ \\
\hline $\begin{array}{c}\text { FST } \\
\text { PHARMACY } \\
\text { HND } \\
\text { ENG } \\
\text { SW }\end{array}$ & $\begin{array}{c}1.566 \\
3.652^{*} \\
2.892 \\
2.675 \\
1.854\end{array}$ & $\begin{array}{c}1.407 \\
4.388^{*} \\
4.172^{*} \\
3.941^{*} \\
2.427\end{array}$ & $\begin{array}{l}3.048 \\
1.922 \\
1.719 \\
1.261 \\
\text { 3.114 }^{*}\end{array}$ & $\begin{array}{c}2.172 \\
-0.450 \\
0.403 \\
-0.103 \\
1.631\end{array}$ & $\begin{array}{l}0.931 \\
0.774 \\
1.436 \\
0.990 \\
1.481 \\
\end{array}$ \\
\hline $\begin{array}{l}\text { PHARMACY } \\
\text { HND } \\
\text { ENG } \\
\text { SW }\end{array}$ & $\begin{array}{l}2.085 \\
1.326 \\
1.109 \\
0.288\end{array}$ & $\begin{array}{l}2.981^{*} \\
2.766 \\
2.535 \\
1.020\end{array}$ & $\begin{array}{c}-1.126 \\
-1.330 \\
-1.787 \\
0.066\end{array}$ & $\begin{array}{l}-2.622 \\
-1.768 \\
-2.275 \\
-0.540\end{array}$ & $\begin{array}{c}-0.157 \\
0.505 \\
0.059 \\
0.551\end{array}$ \\
\hline $\begin{array}{l}\text { HND } \\
\text { ENG } \\
\text { SW }\end{array}$ & $\begin{array}{l}-0.760 \\
-0.976 \\
-1.797\end{array}$ & $\begin{array}{l}-0.216 \\
-0.447 \\
\mathbf{- 1 . 9 6 1 *}\end{array}$ & $\begin{array}{c}-0.203 \\
-0.661 \\
1.192\end{array}$ & $\begin{array}{l}0.854 \\
0.347 \\
\mathbf{2 . 0 8 2}^{*}\end{array}$ & $\begin{array}{l}0.662 \\
0.216 \\
0.707\end{array}$ \\
\hline $\begin{array}{l}\text { ENG } \\
\text { SW }\end{array}$ & $\begin{array}{l}-0.216 \\
-1.038\end{array}$ & $\begin{array}{l}-0.231 \\
-1.745\end{array}$ & $\begin{array}{c}-0.458 \\
1.395\end{array}$ & $\begin{array}{l}-0.506 \\
1.228\end{array}$ & $\begin{array}{c}-0.446 \\
0.046\end{array}$ \\
\hline ENG & -0.821 & -1.514 & 1.853 & 1.734 & 0.492 \\
\hline
\end{tabular}

Notes: ${ }^{a}$ Regarding each of the seven degrees analyzed, the average value of each of the five (sub) dimensions that comprise the consciousness for sustainable consumption (CSC) is indicated. The degrees with more extreme values: higher (or lower) value than 10\% when compared to the average. CSC (for each of its five dimensions) can take values from 1 to 25 and were highlighted in bold, when calculated as the product of Importance (1-5 Likert Scale) and Belief (1-5 Likert Scale). ${ }^{b}$ (Sub) dimension Weighted Average (value of the sub-dimension for the total population) is the weighted (by number of observations in each degree) average of each dimension. ${ }^{c}$ Value of the Brown-Forsythe statistic (robust test of equality of means), where $* * * * * *$ denote significance at $10 \% / 5 \% / 1 \%$. d Value of Tamhane's T2 test of equality of means (not assuming equal variances): Positive values indicate that, for the degree (i), the mean value among its students of the (sub) dimension indicated in the column header is higher than that obtained for the students in the degree (j). Significant differences at $5 \%$ are highlighted in bold and with asterisks. BAM refers to Business Administration and Management Degree; ES: Environmental Science Degree; Pharmacy: Pharmacy Degree; FST: Food Science and Technology Degree; HND: Human Nutrition and Dietetics Degree; ENG: Electric, Electronic, Chemical and Mechanic Engineering Degrees; and SW: Social Work Degree. ENV denotes Environmental Dimension; SOC: Social Dimension; ECON: Economic Dimension, with is built on these three subdimensions: SIMP: Voluntary simplicity, NODEBT: Debt-free consumption and COLLAB: Collaborative consumption. 
Furthermore, the degree of development of each of these five dimensions was not homogeneous for the populations of the seven degrees analyzed. Thus, Environmental Studies (ES) degree students showed a very high degree of development for the five (sub)dimensions of the CSC, while Business Administration \& Management (BAM) students showed low values, generally below the mean.

The statistical analysis of the existence of equality of means for each dimension of sustainability between degrees, taking these in pairs, was performed by Tamhane's post hoc T2 test (not assuming equal variances), and also is shown in Table 5. Focusing on these comparisons, it can emphasize the following significant differences (highlighted in bold) between the degrees:

- $\quad$ The social (SOC) dimension:

- Social Work (SW) students had significantly higher means than Business administration and Management students.

- Environmental Science students had significantly higher means than Business Administration and Management and Pharmacy students.

- The environmental (ENV) dimension is where a greater number of significant differences were observed:

- Environmental Science students had significantly higher means than Business Administration and Management, Pharmacy, Human Nutrition and Dietetics, and Engineering students.

- $\quad$ Food Science and Technology students had significantly higher means than Business Administration and Management, and Pharmacy students.

- Social Work students had significantly higher means than Pharmacy students.

- Found in the sub-dimension Voluntary Simplicity (ECON_SIMP), Environmental Science students had significantly higher means than Social Work students, and finally,

- Regarding the sub-dimension Debt-free Consumption (ECON_NODEBT), Pharmacy students had significantly higher means than Social Work students.

The results obtained led to accepting partially the $\mathrm{H} 2$ hypothesis, as there was some alignment between the choice of the degree and the development of the dimension of sustainability that was most closely linked-although students of Business Administration and Management did not stand out for any of the economic sub-dimensions-students of the most closely related degrees with environmental and social issues (Environmental Science, Food Science, and Social Work, respectively) obtained a particularly high value in related dimensions (ENV and SOC).

\subsection{Relationship between the Level of Studies and the consciousness for sustainable consumption Level}

As has been done previously for each of the degrees, in this section the authors analyzed whether the course the student was taking might have had an influence on the sensitivity or awareness of the student toward sustainable consumption. To do this, the authors performed the same tests of mean differences, but took each of the degrees separately (except for the Environmental degree, since only answers from first-year students were available because during the weeks the questionnaire was distributed there were no fourth grade classes at this grade.

The results obtained on the degrees by applying the Brown-Forsythe test of equality of means on the five sub-dimensions of the consciousness for sustainable consumption (CSC), taking the student's extraction year (first versus final) as a factor and set up in Table 6, showed heterogeneous patterns:

$(=)$ absence of significant differences between first and final year students in Voluntary Simplicity (ECON_SIMP) and Collaborative Consumption (ECON_COLLAB).

(+) significant and positive differences between first and final year students (there is an increase in the last school year versus first school year) in Environmental Dimension (ENV) (in Human Nutrition 
\& Dietetics degree and in Engineering degree) and in Debt-free Consumption subdimension (ECON_NODEBT) (in the TS degree).

$(-) \quad$ significant and negative differences between first and final year students (there was a decrease in the last school year versus the first school year) in Social Dimension (in Business Administration \& Management degree and in Social Work degree) and in Environmental Dimension (in the Food Science \& Technology degree).

Table 6. Brown-Forsythe test of equality of means on the five sub-dimensions of the consciousness for sustainable consumption (CSC), where the student's extraction school year (first versus last) by university degrees that they have studied was taken as a factor.

\begin{tabular}{|c|c|c|c|c|c|c|}
\hline \multirow{2}{*}{$\begin{array}{c}\text { (Sub) } \\
\text { dimensions }\end{array}$} & \multicolumn{6}{|c|}{ Degree } \\
\hline & BAM & FST & PHARMACY & HND & ENG & SW \\
\hline \multirow{2}{*}{ SOC } & $(11.72 ; 11.10)$ & $(16.67 ; 12.66)$ & $(12.30 ; 12.02)$ & $(12.26 ; 14.14)$ & $(13.34 ; 13.04)$ & $(14.86 ; 13.06)$ \\
\hline & 0.350 & $5.19^{* *}$ & 0.062 & 1.126 & 0.048 & $2.842^{*}$ \\
\hline \multirow{2}{*}{ ENV } & $(6.88 ; 7.03)$ & $(13.60 ; 8.88)$ & $(8.43 ; 8.39)$ & $(7.58 ; 10.42)$ & $(7.84 ; 9.84)$ & $(11.04 ; 9.63)$ \\
\hline & 0.042 & $7.47^{* * *}$ & 0.002 & $4.03^{* *}$ & $3.08^{*}$ & 2.688 \\
\hline $\mathrm{ECON}_{-}$ & $(14.88 ; 16.01)$ & $(15.32 ; 13.78)$ & $(15.45 ; 15.70)$ & $(15.93 ; 15.40)$ & $(16.67 ; 15.76)$ & $(14.88 ; 13,74)$ \\
\hline SIMP & 0.944 & 0.781 & 0.084 & 0.201 & 0.882 & 1.457 \\
\hline $\mathrm{ECON}_{-}$ & $(14.75 ; 14.83)$ & $(13.50 ; 14.07)$ & $(16.57 ; 16.25)$ & $(15.31 ; 16.13)$ & $(16.18 ; 16.05)$ & $(13.39 ; 15.50)$ \\
\hline NODEBT & 0.006 & 0.108 & 0.145 & 0.330 & 0.010 & $5.18^{* *}$ \\
\hline $\mathrm{ECON}_{-}$ & $(11.11 ; 11.22)$ & $(11.15 ; 10.50)$ & $(10.43 ; 11.94)$ & $(10.21 ; 10.38)$ & $(10.40 ; 11.02)$ & $(9 . \overline{62 ; 10.90)}$ \\
\hline COLLAB & 0.010 & 0.171 & 2.43 & 0.015 & 0.306 & 2.028 \\
\hline
\end{tabular}

Note: The values in parentheses indicate the mean of each dimension for the first (first digit in parentheses) and last (second digit in parentheses) school year for students in each university degree. The value of the Brown-Forsythe statistic is given below, where $* * * * * * *$ denotes significance at $10 \% / 5 \% / 1 \%$. The significant differences are marked in bold (and underlined those where there was an increase in the last school year versus first school year). This contrast was not achieved in the ES degree due to insufficient data for the final year students. ENV denotes Environmental Dimension; SOC: Social Dimension; ECON: Economic Dimension, with is built on these three subdimensions: SIMP: Voluntary simplicity, NODEBT: Debt-free consumption and COLLAB: Collaborative consumption.

To summarize, there was no significant difference between the first and final school years in the case of Business Administration and Management and Pharmacy. Regarding the degrees in which there were differences, the pattern found was not at all conclusive. The following results can be highlighted:

- The third hypothesis is supported, suggesting that training can improve CSC in only three of the 30 possible cases: in HND and ENG (for the ENV dimension) and in SW (for the ECON_NODEBT dimension).

- The third hypothesis is not supported by 27 of the 30 possible cases. Actually, in three cases, the relationship was contrary to the expectation (in the FST and SW for the SOC dimension, and in FST in the ENV dimension)

These results mean that Hypothesis $\mathrm{H} 3$ is rejected and university education cannot be linked to a greater awareness of sustainability.

\section{Discussion}

First, the analyses revealed the existence of the three dimensions or components of the consciousness for sustainable consumption (CSC) in the Spanish university population: the environmental dimension, the social dimension, and the economic dimension, with the last constructed in turn by three other sub-dimensions (avoidance of financial charges, voluntary simplicity, and collaborative consumption). To respond to the call of Balderjahn et. al [5] (p. 190), in the sense that "future research has been internationalized with respect to measuring CSC around the globe", the authors observed that once applied to a sample of Spanish university students, the CSC scale maintained 
its structure of original dimensions and reflected the main dimensions of the concept of sustainability. This might be due to the similarity (economic and social) of the analyzed population (Álava, Basque Country, an eminently industrial and export-oriented region, with a high environmentally-friendly awareness), similar to the region analyzed in the reference study [5].

Second, the dimension that had a greater explanatory capacity over the CSC was the one related to the social dimension, followed by the economic dimension. This issue aligned with the priority consideration by governments and universities of the Agenda 2030 for Sustainable Development, which takes up the Millennium Development Goals established for the period 2000-2015, and gives new impetus to the commitment to achieve the 17 Sustainable Development Goals that reach five spheres of critical importance to humanity and the planet, with a clear mission and the promise of "leaving no one behind" [93].

Third, it was observed among the three dimensions that make up the CSC that the dimension most developed by students was the economic one (followed by the social dimension), while the least developed was the environmental one, contrasting with the greater attention given by the scientific and international community to this last dimension. Allowing for this, the authors considered it necessary that the academic community should focus more on the economic and social dimensions to balance the importance of the three components that shape sustainability, in congruence with the relative relevance granted by society to each of these three dimensions. Thus, the authors considered that there is an important market niche that companies can address through a competitive strategy by promoting the attributes linked to the social (related to not using child labor or violating human rights, discrimination, abuse, and daily compensation of workers) and economic (sharing versus buying, functionality and durability of goods, etc.) of their goods and services, balancing the majority of effort dedicated to the environmental issue. Truthfully, sustainable consumption will require wider change, including shifts in the incentives that shape the actions of businesses and others, and a change in the culture that underlies market expectations. Businesses, governments, the media, and civil society might need to enter into collaborative dialogue to develop the role of the business community in promoting sustainable consumption [94-96]. Producers and marketers should focus on the functional attributes of the products and make efforts to develop consumer trust in the eco-label. Governments also should monitor the credibility of the messages carried by eco-labels to ensure that the trust of consumers is not being breached [16].

Regarding how these findings provide direction for different faculties/disciplines to incorporate systems thinking, some guidelines are presented for designing curricula in higher education to develop graduate attributes required for achieving sustainability [84]. Tertiary students need opportunities to explore the relevance of concepts such as sustainability in their proposed field of professional practice. The curriculum should include experiences that lead to a greater awareness of social and moral responsibilities. Specifically, greater self-awareness of personal value systems and a willingness to revise them is required to prepare graduates for work toward sustainability.

Among other guidelines, and bearing in mind that if the university wants to be transforming, it must be transformed deeply with changes to teaching and learning [97], the authors propose the following:

i) Faced with the challenge of teaching sustainability educators must move from instructing about sustainability or educating for sustainability (for example, through courses on sustainability) to a more transformative response to make the university a place where students are transformed by the adoption of competences for sustainability [98]. Thus, and as it is done in the BAM Faculty, it is interesting to work on sustainability transversal competence.

ii) There should be emphasis on the participation of students, at different levels of thought, relevance and holistic vision, and not only on cognitive learning, through an innovative methodology, which combines the acquisition of knowledge with its adequate application to educational needs [98]. Thus, and as several authors comment [99,100], learning processes centered on criteria of social justice, equity, and respect for the environment should be used. To this end, the University and some faculties 
are encouraging students to consider the sustainable dimension in their Final Degree Work (FDW) through prizes for the best FDW on sustainability or through student conferences where graduates make a small contribution to the social, environmental and economic transformation of the environment through their FDWs.

iii) While the Higher Education Institutions (HEIs) create knowledge, transfer this knowledge to the society and prepare students for their future role in society, it is necessary that the HEIs contribute to the transition toward a sustainable society [101]. Thus, the different Faculties of this study have a capital importance in the change of mentalities and in the empowerment of youth because the University does not just form competent professionals, but also in transversal competences that have impact in the change of consumption and production toward one placing more responsibility on the students. Since the sustainability of the environment, society and economy is now a mainstream concern [102] and after an Educational Innovation Project entitled Improvement of the perceived importance of 'business sustainability' and its interdisciplinary development as a transversal competence, a Sustainable Management of the Company minor degree has been created.

Likewise, the existence of significant differences between the degrees analyzed could be proven in relation to the level of development of CSC, with it being smaller among Business Administration and Management students with regard to the social and environmental dimensions, which is in line with the differences detected among students of different degrees by other authors [17-20]. Moreover, Social Work students had less developed dimensions related to economic sustainability (in its aspects of voluntary simplicity and avoiding financial charges). Particularly, greater awareness could be observed of students in some degrees (e.g., Environmental Science, Food Science and Technology, Social Work) about the sustainability dimension that a priori would be expected to be more developed. It can be concluded that the choice of degree, in general, is related to a greater awareness of one or another dimension of sustainability. However, this differential or pattern is not recurrent in all of the analyzed degrees.

The relationship between progress in studies and greater environmental awareness could not be verified. It can be concluded, therefore, that the training received in degrees does not help improve the students' level of awareness in their responsible consumption decisions, coinciding with the results of several authors [73-76]. Since this conclusion invites the reader to reject the existence of a direct relationship between the received university formation and sustainable awareness, one must reflect on which formative or communicative measures can be performed at the degree or university campus level to reverse this situation and improve the environmental, social, and economic awareness levels among the university population.

"Thus, some of the formative or communicative measures that should be carried out to improve these levels are the following:

i) Given the lack of training of teachers who have not received training on sustainability [103], it is necessary that the HEIs train teachers, through courses such as the Integration of competencies in Education for Sustainability in university studies and that it be mandatory for the university population.

ii) Given the important role of consumption in the Education for sustainable development (ESD), there is a lack of training and research within the Universities on the importance of education for sustainable consumption (ESC) that has been little studied and under-researched in the HEI [104]. To ameliorate these problems, both curricular and extracurricular projects must be conducted, coinciding with some of the examples that can be found in Barth et al. [105], that work in these areas.

iii) Considering the importance of the SDGs, mainly SDG 12 "Ensure sustainable consumption and production patterns" [106] and SDG 8 "Promote sustained, inclusive and sustainable economic growth, full and productive employment and decent work for all" [106] it is necessary to communicate both inside and outside the university environment in collaboration with other organizations the importance of the SDGs. Thus, in the Campus it is possible to communicate about the SDGs through infographics in the Faculties or open courses where their importance is explained. 
iv) HEIs must embed sustainable development into their academic systems by integrating sustainable development into the HEI's policies and strategies (see $[107,108]$ for examples). Due to the change in the Universities' own management practices [109], it is important that universities make decisions and communicate those good practices in the campus operations and on-campus experiences that they perform. Some examples are the creation of the Observatory of responsible production and consumption, the urban gardens of the Campus, the Good Environmental Practices in Pharmacy, the Environmental Management Systems in Engineering or the Reactivate+ Program of the Faculty of Labor Relations and Social Work that tries to make staff and students aware of the need to reduce the amount of waste.

While the need for curricular and extracurricular actions to promote a sustainable attitude and action among university students is evident [31] by means of collaborative projects regarding the economic and social environment (see for example [41,42]), the proposal is to complete the quantitative analysis performed by expanding the population analyzed to degrees in other areas and/or to other non-university contexts and/or territories (different regions or countries) to see whether there are differences in the results. Likewise, qualitative studies should be implemented to discover effective actions to improve CSC.

Thus, it would be interesting to examine in greater depth, regarding the differences between the degree of development of the dimensions that are part of the CSC, whether the choice of degree is motivated by a greater awareness or development of one dimension (social, economic, or environmental) or whether the training received in each degree strengthens (asymmetrically) one dimension with respect to others. Briefly, it would be advisable to go deeper into the underlying causal relationship, i.e., to analyze whether a greater awareness in a CSC dimension is a precedent, and/or a consequence, of the pursued studies.

Finally, in this article, the beliefs and importance (CSC) that undergraduates held about sustainable consumption were measured only, their real consumption process was not considered. Therefore, even if the thoughts and consciousness of Spanish undergraduates about their consumption could be observed, the real consumption of these early consumers was not measured. Although some authors have measured and developed the sustainable consumption behavior of young consumers [110,111], future research about the real consumption undertaken by these undergraduates would be necessary to observe if there is a real link between consciousness and reality.

Author Contributions: Conceptualization, M.A-M., M.A.P-C., and J.T-N; Data curation, M.A.P-C.; Formal analysis, M.A-M., M.A.P-C., and J.T-N; Funding acquisition, M.A.P-C.; Investigation, M.A-M., M.A.P-C., and J.T-N.; Methodology, M.A-M., M.A.P-C., and J.T-N; Supervision, M.A.P-C and J.T-N.; Validation, M.A-M. and M.A.P-C.; Visualization, J.T-N. and M.A.P-C; Writing—original draft, M.A-M., M.A.P-C., and J.T-N; Writing-review \& editing, J.T-N., M.A.P-C., and M.A-M. All authors have read and approved the final manuscript.

Funding: This research was funded by the FESIDE Foundation (Emilio Soldevilla Foundation for Research and Development of Business Management as a Science) and the UPV/EHU (University of the Basque Country) under grant NUPV12/01.

Acknowledgments: The authors are thankful to Mertxe de Renobales Scheifler, Melchor Gómez Pérez, María del Mar Lledó Sainz de Rozas, and Amaia Inza Bartolomé for the support received. Finally, we thank the anonymous reviewers and editor for their careful reading of our manuscript and their many insightful comments and suggestions.

Conflicts of Interest: The authors declare no conflict of interest. The funders had no role in the design of the study; in the collection, analyses, or interpretation of data; in the writing of the manuscript, or in the decision to publish the results. The findings and conclusions published here are the sole responsibility of the authors.

\section{Appendix A}


Table A1. Questionnaire used to measure Consciousness for Sustainable Consumption (CSC).

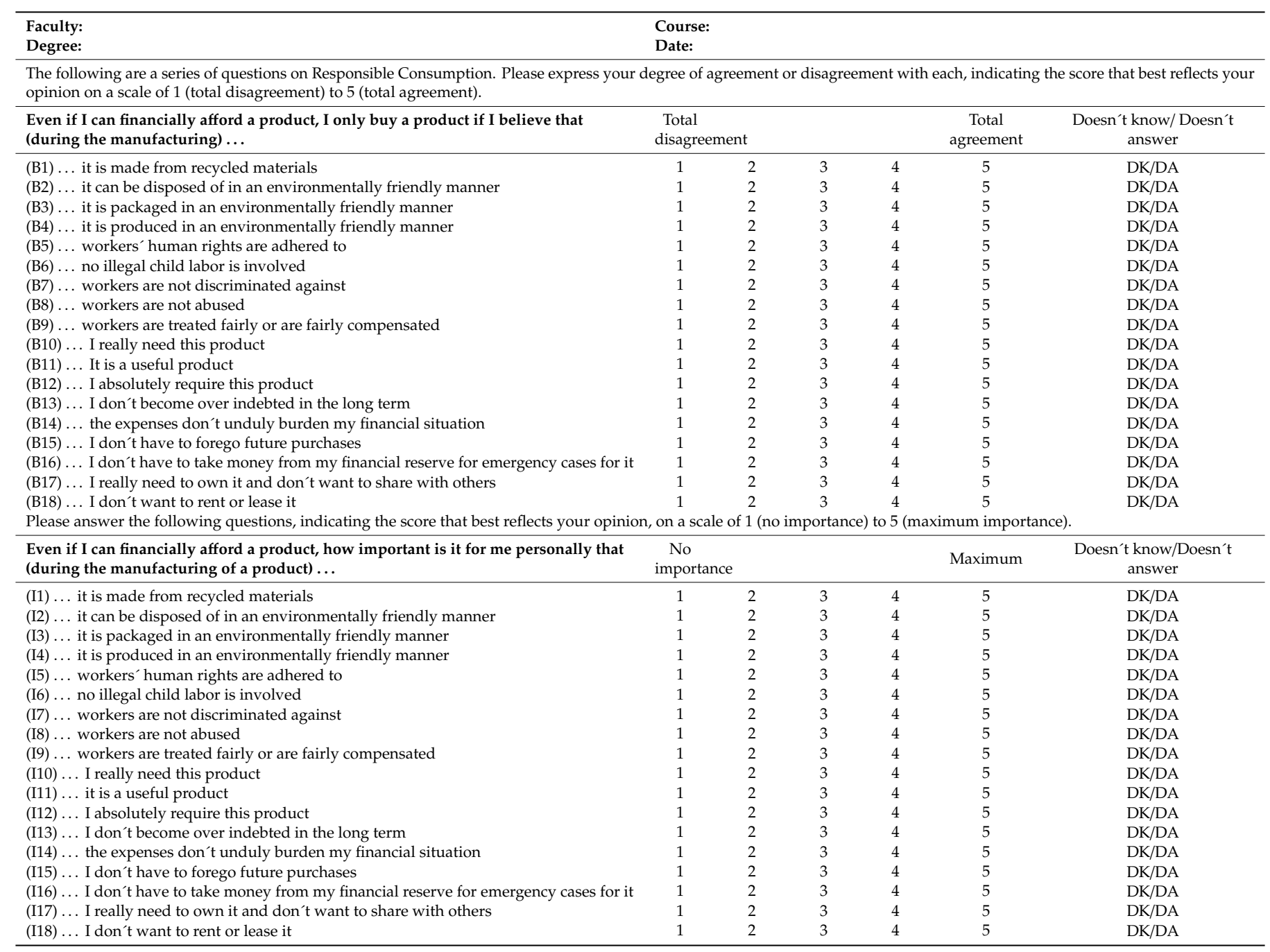

Source: Adapted from [5]. 


\section{References}

1. Khan, E.A.; Quaddus, M. Development and Validation of a Scale for Measuring Sustainability Construct of Informal Microenterprises-A Qualitative and Quantitative Approach. Entrep. Res. J. 2015, 5. [CrossRef]

2. Kim, S.Y.; Yeo, J.; Sohn, S.H.; Rha, J.Y.; Choi, S.; Choi, A.Y.; Shin, S. Toward a composite measure of green consumption: An exploratory study using a Korean sample. J. Fam. Econ. Issues 2012, 33, 199-214. [CrossRef]

3. Tilikidou, I.; Adamson, I.; Sarmaniotis, C. The measurement instrument of ecologically conscious consumer behaviour. MEDIT 2002, 11, 46-53.

4. Sudbury-Riley, L.; Kohlbacher, F. Ethically minded consumer behavior: Scale review, development, and validation. J. Bus. Res. 2016, 6969, 2697-2710. [CrossRef]

5. Balderjahn, I.; Buerke, A.; Kirchgeorg, M.; Peyer, M.; Seegebarth, B.; Wiedmann, K.P. Consciousness for sustainable consumption: Scale development and new insights in the economic dimension of consumers' sustainability. AMS Rev. 2013, 4, 181-192. [CrossRef]

6. Quoquab, F.; Mohammad, J.; Sukari, N.N. A multiple-item scale for measuring "sustainable consumption behaviour" construct: Development and psychometric evaluation. Asia Pac. J. Mark. Logist. 2019. [CrossRef]

7. Gupta, S.; Agrawal, R. Environmentally responsible consumption: Construct definition, scale development, and validation. Corp. Soc. Responsib. Environ. Manag. 2018, 25, 523-536. [CrossRef]

8. Griggs, D.; Stafford-Smith, M.; Gaffney, O.; Rockström, J.; Öhman, M.C.; Shyamsundar, P.; Steffen, W.; Glaser, G.; Kanie, N.; Noble, I. Sustainable development goals for people and planet. Nature 2013, 495, 305-307. [CrossRef]

9. Akenji, L.; Bengtsson, M. Making Sustainable Consumption and Production the Core of Sustainable Development Goals. Sustainability 2014, 6, 513-529. [CrossRef]

10. Jackson, T. Motivating Sustainable Consumption: A Review of Evidence on Consumer Behaviour and Behavioural Change; Sustainable Development Research Network, Policy Studies Institute, University of Surrey: Guildford, UK, 2005.

11. Vermeir, I.; Verbeke, W. Sustainable food consumption: Exploring the consumer 'attitude-behavioral intention' gap. J. Agric. Environ. Ethics 2006, 2, 169-194. [CrossRef]

12. Botsman, R.; Rogers, R. What's Mine Is Yours: The Rise of Collaborative Consumption, 3rd ed.; HarperCollins: New York, NY, USA, 2010.

13. Mcmillin, J.; Dyball, R. Developing a Whole-of-University Approach to Educating for Sustainability: Linking Curriculum, Research and Sustainable Campus Operations. J. Educ. Sustain. Dev. 2009, 1, 55-64. [CrossRef]

14. Nejati, M.; Nejati, M. Assessment of sustainable university factors from the perspective of university students. J. Clean. Prod. 2013, 48, 101-107. [CrossRef]

15. Young, W.; Hwang, K.; McDonald, S.; Oates, C.J. Sustainable consumption: Green consumer behaviour when purchasing products. Sustain. Dev. 2010, 18, 20-31. [CrossRef]

16. Joshi, Y.; Rahman, Z. Factors Affecting Green Purchase Behaviour and Future Research Directions. Int. Strateg. Manag. Rev. 2015, 3, 128-143. [CrossRef]

17. Kagawa, F. Dissonance in students perceptions of sustainable development and sustainability: Implications for curriculum change. Int. J. Sustain. High. Educ. 2007, 3, 317-338. [CrossRef]

18. Sharma, B.; Steward, B.; Ong, S.K.; Miguez, F.E. Understanding engineering students' perceptions and knowledge about sustainable development and sustainability. In Proceedings of the 2014 ASEE North Midwest Section Conference, Iowa City, IA, USA, 16-17 October 2014.

19. Zwickle, A.; Koontz, T.M.; Slagle, K.M.; Bruskotter, J.T. Assessing sustainability knowledge of a student population: Developing a tool to measure knowledge in the environmental, economic and social domains. Int. J. Sustain. High. Educ. 2014, 4, 375-389. [CrossRef]

20. Chiong, K.S. Sustainability Integration into Engineering Curricula within Five Research Universities in Malaysia. Ph.D. Thesis, University of Malaya, Kuala Lumpur, Malaysia, 2015.

21. Connell, K.Y.H.; Kozar, J.M. Sustainability knowledge and behaviors of apparel and textile undergraduates. Int. J. Sustain. High. Educ. 2012, 4, 394-407. [CrossRef]

22. Cotton, D.R.E.; Alcock, I. Commitment to environmental sustainability in the UK student population. Stud. High. Educ. 2013, 10, 1457-1471. [CrossRef]

23. Mathison, M.A.; Stillman-Webb, N.; Bell, S.A. Framing Sustainability: Business Students Writing About the Environment. J. Bus. Tech. Commun. 2014, 1, 58-82. [CrossRef] 
24. Yuan, X.; Zuo, J. A critical assessment of the Higher Education for Sustainable Development from students' perspectives-A Chinese study. J. Clean. Prod. 2013, 48, 108-115. [CrossRef]

25. Hoffman, A.J. Competitive Environmental Strategy: A Guide to the Changing Business Landscape; Island Press: Washington, DC, USA; Covelo, CA, USA, 2000.

26. Thomas, H.; Starkey, K.; Tempest, S. A clear sense of purpose? The evolving role of the business school. J. Manag. Dev. 2008, 27, 379-390.

27. Nicholson, C.Y.; DeMoss, M. Teaching ethics and social responsibility: An evaluation of undergraduate business education at the discipline level. J. Educ. Bus. 2009, 84, 213-218. [CrossRef]

28. Sharma, P.K.; Prashar, S. Understanding of Sustainability amongst Students of Management-A Case of Indian Institute of Management, Raipur, State of Chhattisgarh, India. J. Sustain. Educ. 2017, 16, 1-19.

29. UNCED. Agenda 21, United Nations Conference on Environment and Development; UN General Assembly: New York, NY, USA, 1992.

30. Bahaee, M.; Pérez-Batres, L.A.; Pisani, M.J.; Miller, V.V.; Saremi, M. Sustainable Development in Iran: An Exploratory Study of University Students' Attitudes and Knowledge about Sustainable Development. Corp. Soc. Responsib. Environ. Manag. 2014, 10, 175-187. [CrossRef]

31. Barth, M.; Godemann, J.; Rieckman, M.; Stoltenberg, U. Developing key competences for sustainable development in higher education. Int. J. Sustain. High. Educ. 2007, 4, 416-430. [CrossRef]

32. Dobson, A. Environmental citizenship: Towards sustainable development. Sustain. Dev. 2007, 5, $276-285$. [CrossRef]

33. Leal Filho, W. Sustainability at Universities-Opportunities, Challenges and Trends; Peter Lang D: Bern, Switzerland, 2009; Available online: https://www.peterlang.com/view/title/53372 (accessed on 6 August 2019).

34. Vagnoni, E.; Cavicchi, C. An exploratory study of sustainable development at Italian universities. Int. J. Sustain. High. Educ. 2015, 2, 217-236. [CrossRef]

35. Gombert-Courvoisier, S.; Sennés, V.; Ribeyre, F. An analysis of viewpoints on education for responsible consumption in higher education. Int. J. Sustain. High. Educ. 2014, 3, 259-269. [CrossRef]

36. Amaral, L.P.; Martins, N.; Gouveia, J.B. Quest for a Sustainable University: A review. Int. J. Sustain. High. Educ. 2015, 2, 155-172. [CrossRef]

37. Qian, W. Embracing the Paradox in Educational Change for Sustainable Development: A Case of Accounting. J. Educ. Sustain. Dev. 2013, 1, 75-93. [CrossRef]

38. Hart, S.L. Sustainability must be integral to schools' DNA. Financ. Times 2008, 13, 15.

39. Hahn, T.; Kolk, A.; Winn, M. A new future for business? Rethinking management theory and business strategy. Bus. Soc. 2010, 3, 385-401. [CrossRef]

40. Larran, M.; Andrades, J. Determining factors of environmental education in Spanish universities. Int. J. Sustain. High. Educ. 2015, 2, 251-271. [CrossRef]

41. Holmberg, J.; Lundqvist, U.; Svanström, M.; Arehag, M. The university and transformation towards sustainability: The strategy used at Chalmers University of Technology. Int. J. Sustain. High. Educ. 2012, 3, 219-231. [CrossRef]

42. Orecchini, F.; Valutti, V.; Vitali, G. Industry and academia for a transition towards sustainability: Advancing sustainability science through university-Business collaborations. Sustain. Sci. 2012, 1, 57-73. [CrossRef]

43. Too, L.; Bajracharya, B. Sustainable campus: Engaging the community in sustainability. Int. J. Sustain. High. Educ. 2015, 16, 57-71. [CrossRef]

44. Horhota, M.; Asman, J.; Stratton, J.P.; Halfacre, A.C. Identifying behavioral barriers to campus sustainability: A multi-method approach. Int. J. Sustain. High. Educ. 2014, 3, 343-358. [CrossRef]

45. Chaplin, G.; Wyton, P. Student engagement with sustainability: Understanding the value-action gap. Int. J. Sustain. High. Educ. 2014, 4, 404-417. [CrossRef]

46. Eagle, L.; Low, D.; Case, P.; Vandommele, L. Attitudes of undergraduate business students toward sustainability issues. Int. J. Sustain. High. Educ. 2015, 5, 650-668. [CrossRef]

47. Mckeown, R. Using Rubrics to Assess Student Knowledge Related to Sustainability: A Practitioner's view. J. Educ. Sustain. Dev. 2011, 1,61-74. [CrossRef]

48. Zeegers, Y.; Clark, I.F. Students' perceptions of education for sustainable development. Int. J. Sustain. High. Educ. 2014, 2, 242-253. [CrossRef] 
49. Parece, T.E.; Younos, T.; Grossman, L.S.; Geller, E.S. A study of environmentally relevant behavior in university residence halls. Int. J. Sustain. High. Educ. 2013, 4, 466-481. [CrossRef]

50. Sarkar, M. Secondary Students' Environmental Attitudes: The Case of Environmental Education in Bangladesh. Int. J. Acad. Res. Bus. Soc. Sci. 2011, 1, 106-116.

51. Boyce, T.; Geller, S. Encouraging college students to support pro-environment behaviour: Effects of direct versus indirect rewards. Environ. Behav. 2001, 1, 107-125. [CrossRef]

52. Robinson, Z.P. Are geography students good 'environmental citizens'? A comparison between year of study and over time. J. Geogr. High. Educ. 2015, 2, 245-259. [CrossRef]

53. Abubakar, I.R.; Al-Shihri, F.S.; Ahmed, S.M. Students' Assessment of Campus Sustainability at the University of Dammam, Saudi Arabia. Sustainability 2016, 8, 59. [CrossRef]

54. United Nations. Resolution A/60/1 World Summit Outcome. 2005. Available online: http://www.ifrc.org/ docs/idrl/I520EN.pdf (accessed on 6 August 2019).

55. USEPA. What Is Sustainability? 2014. Available online: https://www.epa.gov/sustainability/sustainabilityand-us-epa (accessed on 6 August 2019).

56. Coyle, K. Environmental Literacy in America: What Ten Years of NEETF/Roper Research and Related Studies Say about Environmental Literacy in the U.S.; National Environmental Education \& Training Foundation: Washington, DC, USA, 2005.

57. Allen, D.; Allenby, B.; Bridges, M.; Criteenden, J.; Davidson, C.; Hendrickson, C.; Mattews, S.; Murphy, C.; Pijawka, D. Benchmarking Sustainable Engineering Education: Final Report; Centre for Sustainable Engineering: Pitsburg, PA, USA, 2008.

58. Pitt, J.; Lubben, F. The social agenda of education for sustainable development within design and technology: The case of Sustainable Design Award. Int. J. Technol. Des. Educ. 2009, 19, 167-186. [CrossRef]

59. Leiserowitz, A.; Smith, N.; Marlon, J.R. American Teens' Knowledge of Climate Change; Yale Project on Climate Change Communication, Yale University: New Haven, CT, USA, 2010; p. 5.

60. Segalas, J.; Mulder, K.F.; Ferrer-Balas, D. What do EESD «experts» think sustainability is? Which pedagogy is suitable to learn it? Int. J. Sustain. High. Educ. 2012, 3, 293-304. [CrossRef]

61. Kovačič, G.; Grubar, V.B. Knowledge of sustainable development among geography students in Slovenia. Acta Geogr. Slov. 2016, 56, 101-111. [CrossRef]

62. Newport, D.; Chesnes, T.; Linder, A. The 'environmental sustainability' problem: Ensuring that sustainability stands on three legs. Int. J. Sustain. High. Educ. 2003, 4, 357-363. [CrossRef]

63. McCormick, M.; Bielefeldt, A.R.; Swan, C.R.; Paterson, K.G. Assessing Students' Motivation to Engage in Sustainable Engineering. Int. J. Sustain. High. Educ. 2015, 2, 136-154. [CrossRef]

64. Vallance, S.; Perkins, H.C.; Dixon, J.E. What is social sustainability? A clarification of concepts. Geoforum 2011, 3, 342-348. [CrossRef]

65. Doane, D.; MacGillivray, A. Economic Sustainability: The Business of Staying in Business; New Economics Foundation: London, UK, 2001; pp. 1-52.

66. Balderjahn, I.; Peyer, M.; Paulssen, M. Consciousness for fair consumption: Conceptualization, scale development and empirical validation. Int. J. Consum. Stud. 2013, 5, 546-555. [CrossRef]

67. Mazis, M.B.; Ahtola, O.T.; Klippel, R.E. A comparison of four multi-attribute models in the prediction of consumer attitudes. J. Consum. Res. 1975, 1, 38-52. [CrossRef]

68. Elkington, J. Cannibals with Forks: The Triple Bottom Line of 21st Century Business, 3rd ed.; Capstone Publication: Oxford, UK, 1997.

69. Pedersen, L.H. The dynamics of green consumption: A matter of visibility? J. Environ. Policy Plan. 2000, 2, 193-210. [CrossRef]

70. Ugulu, I.; Sahin, M.; Baslar, S. High School Students' Environmental Attitude: Scale Development and Validation. Int. J. Educ. Sci. 2013, 4, 415-424.

71. Duram, L.A.; Williams, L.L. Growing a student organic garden within the context of university sustainability initiatives. Int. J. Sustain. High. Educ. 2015, 1, 3-15. [CrossRef]

72. Stark, J.; Park, J.G.P. Interior design students perceptions of sustainability. Int. J. Sustain. High. Educ. 2016, 3 , 361-377. [CrossRef]

73. Kollmus, A.; Agyeman, J. Mind the gap: Why do people act environmentally and what are the barriers to pro-environmental behaviour? Environ. Educ. Res. 2002, 3, 239-260. [CrossRef] 
74. Sammalisto, K.; Sundström, A.; von Haartman, R.; Holm, T.; Yao, Z. Learning about Sustainability-What Influences Students' Self-Perceived Sustainability Actions after Undergraduate Education? Sustainability 2016, 6, 510. [CrossRef]

75. Peattie, K. Golden goose or wild goose? The hunt for the green consumer. Bus. Strategy Environ. 2001, 10, 187-199. [CrossRef]

76. Laroche, M.; Bergeron, J.; Barbaro-Ferleo, G. Targeting customers who are willing to pay more for environmentally friendly products. J. Consum. Mark. 2001, 6, 503-520. [CrossRef]

77. Hochwarter, W. On the merits of student-recruited sampling: Opinions a decade in the making. J. Occup. Organ. Psychol. 2014, 1, 27-33. [CrossRef]

78. Wheeler, A.R.; Shanine, K.K.; Leon, M.R.; Whitman, M.V. Student-recruited samples in organizational research: A review, analysis, and guidelines for future research. J. Occup. Organ. Psychol. 2014, 1, 27-33. [CrossRef]

79. Demerouti, E.; Rispens, S. Improving the image of student-recruited samples: A commentary. J. Occup. Organ. Psychol. 2014, 1, 34-41. [CrossRef]

80. McGorry, S.Y. Measurement in a cross-cultural environment: Survey translation issues. Qual. Mark. Res. Int. J. 2000, 3, 74-81. [CrossRef]

81. Harkness, J.A.; Villar, A.; Edwards, B. Translation, adaptation, and design. Surv. Methods Multinatl. Multireg. Multicult. Contexts 2010, 115-140.

82. Cha, E.; Kim, K.H.; Erlen, J.A. Translation of scales in cross-cultural research: Issues and techniques. J. Adv. Nurs. 2007, 58, 386-395. [CrossRef]

83. Burns, D.J.; Fawcett, J.K.; Lanasa, J. Business students' ethical perceptions of retail situations: A microcultural comparison. J. Bus. Ethics 1994, 13, 667-679. [CrossRef]

84. Knudsen, L.S.; Skovgaard, T.; Bredahl, T. Understanding and scaffolding Danish schoolteachers' motivation for using classroom-based physical activity: Study protocol for a mixed methods study. BMJ Open 2018, 8, e019857. [CrossRef]

85. Davidov, E.; Meuleman, B.; Cieciuch, J.; Schmidt, P.; Billiet, J. Measurement equivalence in cross-national research. Annu. Rev. Sociol. 2014, 40, 55-75. [CrossRef]

86. Krosnick, J.A.; Presser, S. Question and Questionnaire Design. In Handbook of Survey Research, 2nd ed.; Wright, D.J., Marsden, V.P., Eds.; Elsevier: San Diego, CA, USA, 2009; Chapter 9; pp. 263-313.

87. Miller, W.E. American National Election Study, 1980: Pre and Post Election Surveys; Inter-University Consortium for Political and Social Research: Ann Arbor, MI, USA, 1982.

88. Robinson, J.P.; Shaver, P.R.; Wrightsman, L.S. Measures of Political Attitudes; Academic Press: San Diego, CA, USA, 1999.

89. Tavakol, M.; Dennick, R. Making sense of Cronbach's alpha. Int. J. Med. Educ. 2011, 2, 53-55. [CrossRef] [PubMed]

90. Gerbing, D.W.; Anderson, J.C. An updated paradigm for scale development incorporating unidimensionality and its assessment. J. Mark. Res. 1998, 25, 186-192. [CrossRef]

91. Hu, L.; Bentler, P.M. Fit indices in covariance structure modeling: Sensitivity to underparameterized model misspecification. Psychol. Methods 1998, 3, 424-453. [CrossRef]

92. Hair, J.F.; Anderson, R.E.; Tatham, R.L.; Black, W.C. Multivariate Data Analysis; Prentice-Hall: Englewood Cliffs, NJ, USA, 1998.

93. Watkins, K. Leaving no one behind: an agenda for equity. Lancet 2014, 384, 2248-2255. [CrossRef]

94. Michaelis, L. The role of business in sustainable consumption. J. Clean. Prod. 2003, 11, 915-921. [CrossRef]

95. Sibbel, A. Pathways towards sustainability through higher education. Int. J. Sustain. High. Educ. 2009, 10, 68-82. [CrossRef]

96. Jackson, T.; Michaelis, L. Policies for Sustainable Consumption; Sustainable Development Commission: Oxford, UK, 2003.

97. Tilbury, D. Higher education for sustainability: A global overview of commitment and progress. High. Educ. World 2011, 4, 18-28.

98. Painter-Morland, M.; Sabet, E.; Molthan-Hill, P.; Goworek, H.; de Leeuw, S. Beyond the curriculum: Integrating sustainability into business schools. J. Bus. Ethics 2016, 139, 737-754. [CrossRef] 
99. Poza-Vilches, F.; López-Alcarria, A.; Mazuecos-Ciarra, N. A Professional Competences' Diagnosis in Education for Sustainability: A Case Study from the Standpoint of the Education Guidance Service (EGS) in the Spanish Context. Sustainability 2019, 11, 1568. [CrossRef]

100. Jackson, T. The post-growth challenge: Secular stagnation inequality and the limits to growth. Ecol. Econ. 2019, 156, 236-246. [CrossRef]

101. Stough, T.; Ceulemans, K.; Lambrechts, W.; Cappuyns, V. Assessing sustainability in higher education curricula: A critical reflection on validity issues. J. Clean. Prod. 2018, 172, 4456-4466. [CrossRef]

102. Cullen, J.G. Educating business students about sustainability: A bibliometric review of current trends and research needs. J. Bus. Ethics 2017, 145, 429-439. [CrossRef]

103. Aleixo, A.M.; Leal, S.; Azeiteiro, U.M. Conceptualization of sustainable higher education institutions, roles, barriers, and challenges for sustainability: An exploratory study in Portugal. J. Clean. Prod. 2018, 172, 1664-1673. [CrossRef]

104. Barth, M.; Adomßent, M.; Fischer, D.; Richter, S.; Rieckmann, M. Learning to change universities from within: A service-learning perspective on promoting sustainable consumption in higher education. J. Clean. Prod. 2014, 62, 72-81. [CrossRef]

105. Adomssent, M.; Fischer, D.; Godemann, J.; Herzig, C.; Otte, I.; Rieckmann, M.; Timm, J. Emerging areas in research on higher education for sustainable development-management education, sustainable consumption and perspectives from Central and Eastern Europe. J. Clean. Prod. 2014, 62, 1-7. [CrossRef]

106. Le Blanc, D. Towards integration at last? The sustainable development goals as a network of targets. Sustain. Dev. 2015, 23, 176-187. [CrossRef]

107. Lozano, R.; Ceulemans, K.; Alonso-Almeida, M.; Huisingh, D.; Lozano, F.J.; Waas, T.; Lambrechts, W.; Lukman, R.; Hugé, J. A review of commitment and implementation of sustainable development in higher education: Results from a worldwide survey. J. Clean. Prod. 2015, 108, 1-18. [CrossRef]

108. Ramos, T.B.; Caeiro, S.; Van Hoof, B.; Lozano, R.; Huisingh, D.; Ceulemans, K. Experiences from the implementation of sustainable development in higher education institutions: Environmental Management for Sustainable Universities. J. Clean. Prod. 2015, 106, 3-10. [CrossRef]

109. Karatzoglou, B. An in-depth literature review of the evolving roles and contributions of universities to education for sustainable development. J. Clean. Prod. 2013, 49, 44-53. [CrossRef]

110. Fischer, D.; Böhme, T.; Geiger, S.M. Measuring young consumers' sustainable consumption behavior: Development and validation of the YCSCB scale. Young Consum. 2017, 18, 312-326. [CrossRef]

111. Hume, M. Compassion without action: Examining the young consumers consumption and attitude to sustainable consumption. J. World Bus. 2010, 45, 385-394. [CrossRef] 